\title{
Correction to: Diego Velázquez and the Subtle Art of Protest
}

\section{Correction to:}

Chapter 6 in: K. Ingram, Converso Non-Conformism in Early Modern Spain, https://doi.org/10.1007/978-3-319-93236-1_6

The original version of the book was inadvertently published with the below errors:

- In Page 203, in the sentence "It was this same measure that Diego Velázquez would later try to take advantage of in his limpieza examination for entry into the Order of Santiago, in 1558." Year has been updated to 1658 instead of 1558.

- In Page 219, in the sentence "He was, after all, required only to present information about his paternal family line (investigations into candidates' maternal family were not introduced until 1553), and here his Portuguese ancestry would allow him to take advantage of Olivares' patria común measure." Year has been updated to 1653 instead of 1553 .

The chapter has now been corrected and approved by the author.

The updated version of this chapter can be found at https://doi.org/10.1007/978-3-319-93236-1_6

(C) The Author(s) 2020

K. Ingram, Converso Non-Conformism in Early Modern Spain, https://doi.org/10.1007/978-3-319-93236-1_8 